COMPARASON OF LEVELS OF IRON (Fe) ON GREEN SPINACH AND RED AMARANTH THAT ARE SOLD IN THE MARKET SMEP BANDAR LAMPUNG ATOMIC ABSORPTION SPECTROPHOTOMETRY

\title{
PERBANDINGAN KADAR ZAT BESI (Fe) PADA BAYAM HIJAU DAN BAYAM MERAH YANG DIJUAL DI PASAR SMEP BANDAR LAMPUNG SECARA SPEKTROFOTOMETRI SERAPAN ATOM
}

\author{
Nofita $^{1}$, Robby Candra Purnama ${ }^{2}$, Mochammad Arief Hidayat ${ }^{2}$ \\ Email : nofita82apt@gmail.com
}

\begin{abstract}
Spinach is a green vegetable that grows throughout the year, the spinach is sold in the market and known commonly consumed green spinach and red amaranth. Spinach banya widely consumed because it contains iron (Fe). Iron is useful for preventing anemia. People still think that is still a seasonal red spinach contains more iron than spinach green that can be found at any time. This study aims to determine whether there is a significant difference between green and red spinach spinach. Samples obtained from traditional market, Pasar In Bandar Lampung SMEP. Samples were taken at random, used as a sample two samples. Samples to be analyzed first prepared. The instrument used for the analysis of iron which SHIMADZU Atomic Absorption Spectrophotometer AA7000 with a wavelength of $248.44 \mathrm{~nm}$ obtained. Obtained linear regression equation $y=$ $0,105456 x+0.002378$ with a correlation coefficient $(r)=0.9999$. The average level of iron in spinach greens $0.0740 \mathrm{mg} / 100 \mathrm{~g}$ and an average iron in red spinach $2.0744 \mathrm{mg} /$ $100 \mathrm{~g}$. $T$ test calculations obtained from $t=6.6744$ compared to ttabel confidence level of $99 \%$ which is 4.60. If thitung greater than ttable so $\mathrm{Ha}$ is received, so it can be concluded that Ha Ho accepted and rejected, and there is a significant difference between green and red spinach spinach sold in markets SMEP Bandar Lampung. Thus, the Fe content is greater than the red spinach green spinach.
\end{abstract}

Keywords: Fe, green spinach, red spinach, atomic absorption spectrophotometry

\section{ABSTRAK}

Bayam merupakan sayuran hijau yang tumbuh sepanjang tahun, bayam yang dijual di pasaran dan biasa dikonsumsi dikenal bayam hijau dan bayam merah. Bayam banyak dikonsumsi karena banya mengandung zat besi (Fe). Zat besi berguna untuk mencegah anemia. Masyarakat masih menganggap bayam merah yang masih musiman lebih banyak mengandung zat besi dari pada bayam hijau yang bisa ditemui kapan saja. Penelitian ini bertujuan untuk mengetahui apakah ada perbedaan signifikan antara bayam hijau dan bayam merah. Sampel didapatkan dari Pasar Tradisional Di Bandar Lampung yaitu Pasar Smep. Sampel dilakukan secara random, sampel yang digunakan sebanyak dua sampel. Sampel yang akan dianalisa terlebih dahulu dipreparasi. Instrumen yang digunakan untuk analisa zat besi yaitu Spektrofotometri Serapan Atom SHIMADZU AA-7000 dengan didapat panjang gelombang 248,44 nm. Didapat persamaan regresi linear $y=0,105456 x+0,002378$ dengan nilai koefisien korelasi $(r)=0,9999$. Kadar rata-rata zat besi pada bayam hijau $0,0740 \mathrm{mg} / 100 \mathrm{~g}$ dan rata-rata zat besi pada bayam merah $2,0744 \mathrm{mg} / 100 \mathrm{~g}$. Dari perhitungan $\mathrm{uji} t$ didapat $\mathrm{t}_{\text {hitung }}=6,6744$ yang dibandingkan dengan $t_{\text {tabel }}$ dengan taraf kepercayaan $99 \%$ yaitu 4,60 . Jika $t_{\text {hitung }}$ lebih besar dari $t_{\text {tabel }}$ maka Ha diterima, sehingga dapat disimpulkan bahwa Ha diterima dan Ho ditolak dan terdapat perbedaan signifikan antara bayam hijau dan bayam merah yang dijual di Pasar Smep Bandar Lampung.Dengan demikian, kadar Fe bayam merah lebih besar dari bayam hijau.

Kata kunci : Fe, bayam hijau, bayam merah, spektrofotometri serapan atom

1) Prodi Farmasi Universitas Malahayati

2) Prodi DIII Analisis Farmasi Dan Makanan Universitas Malahayati 


\section{PENDAHULUAN}

Bayam (Amaranthus sp.) berasal dari Amerika. Sampai sekarang, tumbuhan ini sudah tersebar di daerah tropis dan subtropis seluruh dunia. Di Indonesia, bayam dapat tumbuh sepanjang tahun dan ditemukan pada ketinggian 5-2.000 m dpl, tumbuh di daerah panas dan dingin, tetapi tumbuh subur di daratan rendah pada lahan terbuka yang udaranya agak panas. Bayam yang dijual di pasaran dan biasa dikonsumsi sebagai sayuran yang dikenal dengan bayam cabutan atau bayam sekul, adapula varietas bayam yaitu bayam hijau dan bayam merah yang daun dan batangnya berwarna merah [7].

Untuk makanan yang mengandung zat gizi seperti zat besi, masyarakat bisa mengkonsumsi dari makanan seperti daging, kuning telur, kacang-kacangan dan sayuran hijau. Salah satu sayuran hijau yang mengandung zat besi yaitu sayuran bayam. Bayam merupakan sejenis tumbuhan yang biasa ditanam untuk dikonsumsi daunnya sebagai sayuran hijau. Bayam banyak mengandung vitamin $A, B$, dan $C$, selain itu bayam banyak mengandung garamgaram mineral yang penting seperti kalsium, fosfor, dan besi. Bayam mengandung zat mineral tinggi yaitu zat besi untuk mendorong pertumbuhan badan dan menjaga kesehatan [8].

Zat besi merupakan mikro yang paling banyak terdapat di dalam tubuh manusia, yaitu sebanyak 3-4 gram di dalam tubuh manusia dewasa. Zat besi mempunyai beberapa fungsi esensial di dalam tubuh, sebagai alat angkut oksigen dari paru-paru ke jaringan tubuh, sebagai alat angkut elektron di dalam sel, dan sebagai bagian terpadu berbagi reaksi enzim di dalam jaringan tubuh. Walaupun terdapat luas di dalam makanan banyak penduduk dunia mengalami kekurangn zat besi, termasuk di Indonesia [1].

Sehingga penting dilakukan penelitian untuk mengetahui apakah ada perbedaan kadar zat besi yang terkandung dalam kedua sampel bayam merah dan bayam hijau menggunakan metode Spektrofotometri Serapan Atom.

Spektrofotometri serapan atom digunakan untuk analisis kuantitatif unsur-unsur logam dalam jumlah sekelumit (trace) dan sangat kelumit (ultra trace). Cara ini cocok untuk analisis sekelumit logam karena mempunyai kepekaan yang tinggi (batas deteksi kurang dari $1 \mathrm{ppm}$ ). Metode ini mendasarkan pada hukum Lambert-Beer [3].

\section{METODOLOGI PENELITIAN Tempat dan Waktu Penelitian \\ 1. Alat}

Alat-alat yang digunakan adalah alat-alat gelas, bulp, mortir dan stamper, pipet ukur, neraca listrik, batang pengaduk, oven, Hotplate, Spektrofotometri Serapan Atom AA 7000 dan lampu katoda besi (Fe).

\section{Bahan}

Bahan-bahan yang digunakan adalah sampel bayam merah dan bayam hijau, $\mathrm{HNO}_{3}$ Pekat, larutan $\mathrm{HNO}_{3} 0,1$ $\mathrm{N}$, larutan $\mathrm{Fe}\left(\mathrm{NO}_{3}\right)_{3} 1000 \mathrm{mg} / \mathrm{L}$, Aquadest, dan tissu.

\section{PROSEDUR PENELITIAN}

\section{Sampel}

Sampel yang akan digunakan dalam penelitian ini adalah sayuran bayam hijau dan bayam merah yang dijual di Pasar Smep Bandar Lampung, yang masing-masing diwakili satu sampel bayam hijau dan satu bayam merah.

\section{Preparasi Sampel}

Batang dan daun bayam dicuci bersih lalu dikeringkan dalam oven. Digerus dan ditimbang masingmasing 5 gram, lalu dipijarkan sampai diperoleh abu berwarna keputih-putihan. Kemudian abu yang diperoleh ditetesi sedikit demi sedikit dengan $\mathrm{HNO}_{3} 0,1 \mathrm{~N}$ sebanyak $5 \mathrm{~mL}$, lalu dipanaskan sampai kering diatas lempeng pemanas, dinginkan kembali. Kemudian dilarutkan dengan 2,5 mL $\mathrm{HNO}_{3}$ Pekat sedikit demi sedikit hingga abu larut. Larutan tersebut dimasukkan kedalam labu takar $50 \mathrm{~mL}$ dan dicukupkan volumenya sampai tanda batas, kemudian diukur menggunakan Spektrofotometri Serapan Atom [2]. 


\section{Pembuatan Larutan Baku $\mathbf{5 0}$ ppm}

Dipipet $5 \mathrm{~mL}$ larutan $\mathrm{Fe}\left(\mathrm{NO}_{3}\right)_{3} 1000$ $\mathrm{mg} / \mathrm{L}$ pm lalu dimasukkan ke dalam labu ukur $100 \mathrm{~mL}$. Selanjutnya ditambahkan menggunakan $\mathrm{HNO}_{3}$ $0,1 \mathrm{~N} 5 \mathrm{ml}$, dan tambah aquadest hingga tanda batas kemudian dihomogenkan [6].

4. Pembuatan Larutan standar 0,25 ppm, 0,5 ppm, 1 ppm, 2 ppm, 3 ppm, dan 4 ppm

Dipipet larutan baku 50 ppm masing-masing $0,25 \mathrm{~mL}, 0,5 \mathrm{~mL}, 1$ $\mathrm{mL}, 2 \mathrm{~mL}, 3 \mathrm{Ml}$, dan $4 \mathrm{~mL}$. Lalu dimasukkan ke dalam masingmasing labu ukur $50 \mathrm{~mL}$. Selanjutnya masing-masing isi labu ukur ditambah dengan menggunakan $\mathrm{HNO}_{3}$ 0,1 N $5 \mathrm{~mL}$, dan tambah aquadest hingga tanda batas dan dihomogenkan. Kemudian diukur absorbansinya dengan SSA [6].

\section{Pembuatan Kurva Kalibrasi}

Pembuatan kurva kalibrasi dilakukan dengan tahapan sebagai berikut:

Alat SSA diatur dan dioptimalkan dengan menekan tombol start ikuti petunjuk penggunaan alat yang tertera pada monitor.

Larutan seri standar kemudian diukur dengan alat SSA, lalu dicatat hasil serapannya.

Kurva kalibrasi dibuat berdasarkan data-data yang telah diperoleh dan ditentukan persamaan garus lurusnya yaitu $\mathrm{y}=\mathrm{ax}+\mathrm{b}$.

\section{Penetapan Kadar zat besi pada} Bayam Hijau dan Bayam Merah

Untuk mencari konsentrasi sampel dicari dengan menggunakan metode kurva kalibrasi, yaitu kurva yang menghubungkan absorban dengan konsentrasi standar. Kurva kalibrasi ini kemudian digunakan untuk mengalurkan absorban yang dihasilkan dari larutan sampel. Setelah didapat absorban dari

\author{
larutan sampel maka untuk \\ menentukan konsentrasinya \\ digunakan rumus regresi linier \\ berdasarkan kurva kalibrasi. Data \\ hasil pengamatan larutan standar \\ dimasukkan ke dalam tabel dengan \\ menggunakan persamaan regresi \\ linear dengan rumus $Y=a x+b$ \\ $\mathrm{y}=$ absorbansi larutan sampel \\ $\mathrm{a}=$ slope \\ $\mathrm{x}=$ konsentrasi larutan sampel \\ $\mathrm{b}=$ intercept \\ Dari pengukuran absorbansi dari tiap \\ pengulangan tiap sampel, \\ absorbansi dimasukkan ke dalam \\ persamaan regresi linier. Dari \\ regresi linier didapat kadar sampel \\ tiap pengulangan (ppm) menjadi \\ (mg/100 gram) \\ Rumus $\frac{\mathrm{C} \times \mathrm{V}}{\mathrm{W}}$ \\ Keterangan : \\ $\mathrm{C}=$ Konsentrasi $(\mathrm{mg} / \mathrm{L})$ \\ $\mathrm{V}=$ Volume Larutan $(\mathrm{L})$ \\ $\mathrm{W}=$ Berat sampel $(\mathrm{kg})$
}

\section{Analisa Data}

Analisa statistika (Uji t) adalah satu uji statistik yang digunakan untuk mengetahui ada atau tidaknya perbedaan yang signifikan (meyakinkan) dari dua buah mean sampel dari dua buah variabel yang telah dikomparatifkan. Cara menarik kesimpulan dari uji t yaitu memberikan interpretasi terhadap $t_{0}$ dengan merumuskan hipotesa alternatif $\left(\mathrm{H}_{\mathrm{A}}\right)$ yang menyatakan ada perbedaan dan hipotesa nol $\left(\mathrm{H}_{\mathrm{O}}\right)$ yang menyatakan tidak ada perbedaan. Setelah itu mencari df atau $\mathrm{db}$, lalu dengan besarnya df atau $\mathrm{db}$ tersebut berkonsultasi pada tabel nilai " $t$ " hasilnya disebut $t$ tabel ( $\left.t_{\text {tabel }}\right)$. Selanjutnya dibandingkan $t_{0}$ dengan $t_{\text {tabel }}$ dengan ketentuan :

Bila $t_{0}$ sama dengan atau lebih besar dari $t_{\text {tabel }}$ maka hipotesis nol $\left(\mathrm{H}_{\mathrm{O}}\right)$ ditolak, yang berarti ada perbedaan yang segnifikan.

Bila $t_{0}$ lebih kecil dari $t_{\text {tabel }}$ maka hipotesa nol $\left(\mathrm{H}_{\mathrm{O}}\right)$ diterima, yang berarti tidak ada perbedaan yang signifikan [5]. 
HASIL DAN PEMBAHASAN

Tabel 1

Absorbansi larutan standar Besi (Fe)

\begin{tabular}{ccc}
\hline Standar & Konsentrasi (ppm) & Absorbansi \\
\hline Blanko & 0,0 & 0,0008 \\
Standar 1 & 0,25 & 0,0286 \\
Standar 2 & 0,5 & 0,0561 \\
Standar 3 & 1 & 0,1080 \\
Standar 4 & 2 & 0,2150 \\
Standar 5 & 3 & 0,3182 \\
Standar 6 & 4 & 0,4236 \\
\hline
\end{tabular}

\section{Kurva Kalibrasi}

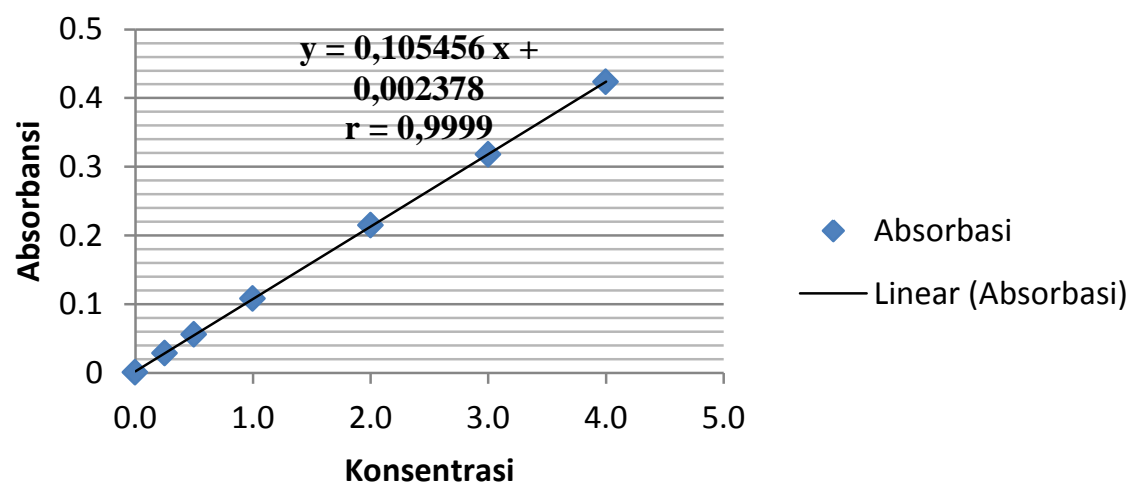

Tabel 2

Hasil kadar zat besi (Fe) pada bayam hijau dan bayam merah

\begin{tabular}{cccccc}
\hline Sampel & Pengulangan & $\begin{array}{c}\text { Berat } \\
\text { Sample } \\
(\mathrm{gram})\end{array}$ & $\begin{array}{c}\text { Konsentrasi } \\
\text { Besi (Fe) } \\
(\mathrm{ppm})\end{array}$ & $\begin{array}{c}\text { Kadar Fe } \\
(\mathrm{mg} / 100 \mathrm{~g})\end{array}$ & $\begin{array}{c}\text { Kadar } \\
\text { rata-rata } \\
(\mathrm{mg} / 100 \mathrm{~g})\end{array}$ \\
\hline Bayam & 1 & 5,0016 & 0,0685 & 0,0684 & \\
hijau & 2 & 5,0018 & 0,0789 & 0,0788 & 0,0740 \\
& 3 & 5,0019 & 0,0751 & 0,0750 & \\
Bayam & 1 & 5,0017 & 2,2476 & 2,2468 & 2,0744 \\
merah & 2 & 5,0025 & 2,4913 & 2,4899 & \\
\hline
\end{tabular}

Tabel 3

Hasil mean dan standar deviasi untuk memperoleh harga "t"

\begin{tabular}{|c|c|c|c|c|c|}
\hline \multicolumn{2}{|c|}{ Nilai } & \multirow[b]{2}{*}{$\mathrm{x}$} & \multirow[b]{2}{*}{ y } & \multirow{2}{*}{$x^{2}$} & \multirow{2}{*}{$y^{2}$} \\
\hline $\mathrm{X}$ & $\mathrm{Y}$ & & & & \\
\hline 2,2468 & 0,0684 & 0,1724 & $-0,0056$ & 0,0297 & 0,00003 \\
\hline 2,4899 & 0,0788 & 0,4155 & 0,0047 & 0,1726 & 0,00002 \\
\hline 1,4865 & 0,0750 & $-0,5879$ & 0,0009 & 0,3456 & 0,0000008 \\
\hline$\Sigma X=6,2232$ & $\Sigma Y=0,2222$ & $\sum x=0$ & $\Sigma y=0$ & $\Sigma x^{2}=0,5479$ & $\Sigma y^{2}=0,00005$ \\
\hline
\end{tabular}


Tabel 4

Data Hasil Uji t

\begin{tabular}{|c|c|c|c|c|c|c|c|}
\hline \multirow{2}{*}{ Sampel } & \multirow{2}{*}{$\begin{array}{c}\text { Kadar rata-rata } \\
(\mathrm{mg} / 100 \mathrm{~g})\end{array}$} & \multirow{2}{*}{$\mathrm{N}$} & \multirow{2}{*}{ df } & \multirow{2}{*}{$\%$} & \multicolumn{2}{|c|}{ Uji t } & \multirow{2}{*}{ kesimpulan } \\
\hline & & & & & $t_{\text {hitung }}$ & $t_{\text {tabel }}$ & \\
\hline $\begin{array}{l}\text { Bayam Merah (N1) } \\
\text { Bayam Hijau (N2) }\end{array}$ & $\begin{array}{l}2,0744 \\
0,0740\end{array}$ & $\begin{array}{l}3 \\
3\end{array}$ & 4 & $99 \%$ & 6,6744 & 4,60 & $t_{\text {hitung }}>t_{\text {tabel }}$ \\
\hline
\end{tabular}

Keterangan

$\mathrm{N}$

df : Derajat freedom (kebebasan)

$\% \quad$ : Taraf Kepercayaan

$t_{\text {hitung }}>t_{\text {tabel }} \quad:$ Ha diterima dan Ho ditolak, sehingga terdapat perbedaan yang signifikan antara kadar Fe pada bayam hijau dan bayam merah.

\section{PEMBAHASAN}

Penetapan kandungan logam mineral Fe yang dilakukan pada bayam hijau dan bayam merah diambil di bagian batang dan daun yang masih segar. Untuk mengurangi kadar air yang terkandung dalam bayam terlebih dahulu di oven hingga kering pada suhu \pm $105^{\circ} \mathrm{C}$ selama 4 jam. Sampel yang sudah kering dan bisa diserbukkan kemudian dapat ditimbang masing-masing penguluangan dari sampel bayam hijau dan bayam merah seberat 5 gram.

Alat yang digunakan untuk menganalisi kandungan zat besi pada penelitian ini menggunakan Spektrofotometri Serapan Atom SHIMADZU AA-7000. Dengan alat ini mineral besi pada sampel dapat terbaca, Spektrofotometri Serapan Atom dapat digunakan untuk analisis kuantitatif mineral dalam jumlah yang sekelumit dan sangat kelumit, memiliki kepekaan yang tinggi, dan pelaksanaanya relatif sederhana [3].

Pada penentuan kadar besi (Fe) diawali dengan penentuan panjang gelombang maksimum. Penentuan panjang gelombang maksimum dilakukan untuk mengetahui dimana terjadi absorpsi maksimum. Pada pengukuran panjang gelombang lampu katoda Fe memberikan serapan tertinggi pada panjang gelombang 248,44 $\mathrm{nm}$. Setelah dilakukan pengukuran panjang gelombang maksimum kemudian membuat kurva kalibrasi. Tujuan dari pembuatan kurva kalibrasi yaitu untuk menghitung kadar zat besi dalam sampel berdasarkan serapan yang dihasilkan melalui persamaan kurva kalibrasi. Pembuatan kurva kalibrasi didahului dengan pembuatan larutan seri dengan pengenceran dari larutan standar besi untuk mendapakatkan konsentrasi yang diinginkan. Pengenceran larutan induk besi dilakukan dengan teliti dan hati-hati supaya tidak terjadi kesalahan yang dapat menyebabkan konsentrasi larutan standar yang tidak sesuai dengan yang diinginkan.

Dalam pengukuran larutan standar besi dilakukan pada panjang gelombang yang sudah didapat dalama pengukuran serapan tertinggi yaitu 284,44 nm kemudian serapan yang diperoleh ditetapkan kedalam kurva kalibrasi sehingga diperoleh kurva kalibrasi besi dengan persamaan kurva kalibrasi $\mathrm{y}=$ ax + b. Kurva kalibrasi larutan dibuat dari enam seri dengan konsentrasi 0,25 ppm, 0,5 ppm, 1 ppm, 2 ppm, 3 ppm, dan $4 \mathrm{ppm}$. Larutan seri tersebut dibuat dari pengenceran larutan induk $\mathrm{Fe}\left(\mathrm{NO}_{3}\right)_{3}$ $100 \mathrm{ppm}$, yang diperoleh dari pengenceran larutan induk $\mathrm{Fe}\left(\mathrm{NO}_{3}\right)_{3}$ 1000 ppm yang sudah tersedia dalam bentuk larutan. Persamaan yang didapat adalah $y=0,105456 x+0,002378$ dengan nilai koefisien korelasi ( $r$ ) adalah 0,9999 . Nilai koefisien korelasi ( $r$ ) adalah bilangan yang digunakan untuk mengetahui kuat, sedang, dan lemahnya hubungan di antara variabel yang sedang diteliti yang berarti semakin mendekati nilai 1 maka semakin kuat. Nilai koefisien korelasi ( $r$ ) dan kurva kalibrasi larutan besi (Fe) adalah 0,9999 yang maka hal ini menunjukan bahwa hasil $r$ sangat kuat, karena menunjukan tingkat hubungan linier yang sangat kuat antara $x$ (konsentrasi larutan standar besi) dan y (absorbansi larutan standar besi). 
Sampel sebelum dianalisis terlebih dahulu mengalami preparasi, hal yang pertama dengan mencuci bersih sampel yang akan dianalisis. Kemudian sampel bayam dipotong bagian daun dan batangnya. Untuk mengurangi kadar air dan sebelum diabukan harus melalui pengeringan dengan menggunakan oven dengan suhu $\pm 105^{\circ} \mathrm{C}$ selama 4 jam. Sampel yang sudah kering dan dapat dihaluskan lalu ditimbang \pm 5 gram, sampel kemudian di dalam tanur selama 6 jam pada suhu $400{ }^{\circ} \mathrm{C}$ untuk menghilangkan zat-zat organik yang tidak dibutuhkan dan menyisahkan zat yang tidak menguap dalam suhu tinggi kemudian didapat abu putih. Setelah mendapatkan abu putih kemudian didestruksi yaitu destruksi basah dengan penambahan larutan $\mathrm{HNO}_{3} \quad 0,1 \mathrm{~N}$ sebanyak $5 \mathrm{ml}$ perlahan dan dipanaskan di atas hotplate dengan suhu $\pm 100{ }^{\circ} \mathrm{C}$, karena larutan hanya $5 \mathrm{ml}$ pemanasan tidak terlalu lama sampai larutan terbentuk endapan kering. Lalu ditambah 2,5 $\mathrm{ml} \mathrm{HNO}_{3}$ pekat dan dihomogenkan, kemudian dimasukkan kedalam labu terukur $50 \mathrm{ml}$ lalu tambah dengan aquadest hingga garis tanda.

Setelah sampel ditambah dengan aquadest masih sedikit keruh harus di saring kembali, karena dalam pengukuran menggunakan Spektrofotometri Serapan Atom larutan yang akan diukur harus jernih dan tidak ada lagi sisa zat pengotor yang ada dalam labu. Penyaringan menggunakan kertas Whatman No. 40 sehingga didapatkan larutan yang jernih dan zat pengotor dapat terpisah dengan sempurna, kemudian larutan yang sudah mengalami penyaringan dilakukan pengukuran kadar besi (Fe) dalam sampel dengan menggunakan Spektrofotometri Serapan Atom SHIMADZU AA-7000, dengan dilengkapi hollow cathode lamp Fe (besi).

Berdasarkan hasil analisa kadar zat besi pada bayam hijau dan bayam merah memiliki perbedaan yang signifikan. Kadar rata-rata zat besi dari bayam hijau adalah 0,0740 $\pm 0,0032$ $\mathrm{mg} / 100 \mathrm{~g}$ dan rata-rata kadar zat besi bayam merah adalah 2,0744 $\pm 0,4273$ $\mathrm{mg} / 100 \mathrm{~g}$. Nilai SD dari sampel bayam merah cukup besar, namun masih dalam kategori cukup [4], oleh karena itu ketiga data dari bayam merah masih bisa digunakan untuk menentukan kadar rata-rata. Perbedaan kadar $\mathrm{Fe}$ pada bayam hijau dan bayam merah bisa disebabkan dari proses penanaman, penggunaan pupuk yang berbeda karena dari penjual memberikan informasi bahwa bayam merah bisa didapatkan musiman saja berbeda dengan bayam hijau yang selalu ada tanpa musiman. Sehingga faktor-faktor tersebut dapat menyebabkan terjadi perbedaan kadar Fe pada bayam hijau dan bayam merah.

Sebelum dimasukkan ke dalam rumus uji $t$, terlebih dahulu dihitung nilai rata-rata dari kedua variabel dan standar defiasi (SD), setelah nilai masing-masing didapatkan maka dimasukkan kedalam uji t. Hasil dari perhitungan uji $t$ didapatkan bahwa $t_{\text {hitung }}=6,6744$ Nilai $t_{\text {hitung }}$ ini akan dibandingkan dengan $t_{\text {tabel }}$ yang didapat dengan menghitung derajat kebebasan (df) dengan rumus (N1+N2)$2=(3+3)-2=4$ sehingga didapat $t_{\text {tabel }}$ yaitu taraf kepercayaan $99 \%$ yaitu 4,60 . Jika $t_{\text {hitung }}$ lebih besar dari $t_{\text {tabel }}$ maka $\mathrm{Ha}$ diterima dan Ho ditolak sedangkan jika $t_{\text {hitung }}$ lebih kecil dari $t_{\text {tabel }}$ maka $\mathrm{Ha}$ ditolak dan Ho diterima, sehingga dari data diatas dapat disimpulkan bahwa $\mathrm{Ha}$ diterima dan Ho ditolak sehingga terdapat perbedaan yang signifikan antara zat besi bayam hijau dan bayam merah yang dijual di Pasar Smep Bandar Lampung [5].

\section{KESIMPULAN}

1. Dari data sampel yang didapat, kadar rata-rata zat besi pada bayam hijau yaitu $0,0740 \mathrm{mg} / 100 \mathrm{~g}$, dan untuk rata-rata kadar zat besi pada bayam merah yaitu 2,0744 $\mathrm{mg} / 100 \mathrm{~g}$.

2. Data yang didapat dari kedua sampel terdapat perbedaan yang signifikan kadar zat besi bayam hijau dan bayam hijau bahwa kadar zat besi $\left(\mathrm{Fe}\right.$ ) didapat $\mathrm{t}_{\text {hitung }}=6,6744$ lebih besar dari $t_{\text {tabel }}$ pada taraf signifikan $99 \%=4,60$ dengan nilai $\mathrm{df}=4$.

\section{SARAN}

1. Kadar zat besi bayam merah lebih tinggi dibandingkan dengan bayam hijau, sehingga disarankan untuk mengkonsumsi bayam merah yang 
mempunyai kandungan zat besi yang lebih tinggi walaupun bayam merah masih jarang ditemui di pasar tradisional karena musiman.

2. Mengkonsumsi bayam merah maupun bayam hijau keduanya adalah sayuran yang sangat baik untuk memenuhi kebutuhan zat besi dalam tubuh.

3. Melakukan penelitian lebih lanjut mengenai membandingkan kadar cemaran logam berat dalam bayam merah maupun bayam hijau yang dijual di swalayan/supermarket dengan yang dijual di pasar tradisional.

\section{DAFTAR PUSTAKA}

1. Almatsier. Sunita. 2009. Prinsip Dasar Ilmu Gizi. Gramedia Pustaka Utama. Jakarta.

2. Fitriawati, E. 2016. Analisis Kadar Besi Dalam Bayam (Amaranthus tricolor) dengan Spektrofotometri
Serapan Atom. Jurnal. Universitas Sumatra Utara. Medan.

3. Gandjar, I. G., Rohman, A. 2012. Analisi Obat Secara Spektrofotometri dan Kromatografi. Pustaka Pelajar. Yogyakarta.

4. Handoko, Riwidikdo. 2009. Statistik Kesehatan. Mitra Cedikia Press. Yogyakarta.

5. Hartono. 2008. Statistika Untuk Penelitian. Pustaka Pelajar. Yogyakarta.

6. Saleh, S. 2011. Kimia Analitik Analisis Unsur Fe Dalam Tanaman Bayam Dengn Menggunakan Spektrofotometri Serapan Atom. Jurnal. Universitas Hasanuddin. Makassar.

7. Setiawan. 2006. Atlas Tumbuhan Obat Indenisa Jilid 2. Trubus Agriwidya. Jakarta.

8. Sunarjono, Hendro. 2003. Bertanam 30 Jenis Sayuran. Penebar Swadaya. Jakarta. 